\title{
Enzyme-assisted extraction (EAE) for the production of antiviral and antioxidant extracts from the green seaweed Ulva armoricana (Ulvales, Ulvophyceae)
}

\author{
Hardouin Kevin ${ }^{1,2, *}$, Bedoux Gilles ${ }^{1}$, Burlot Anne-Sophie ${ }^{1}$, Donnay-Moreno Claire ${ }^{4}$, \\ Bergé Jean-Pascal ${ }^{5}$, Nyvall-Collén $\mathrm{Pi}^{3,5}$, Bourgougnon Nathalie ${ }^{1}$
}

${ }^{1}$ Univ Bretagne Sud, LBCM, IUEM, EA 3884, F-56000 Vannes, France.

${ }^{2}$ SA OLMIX, ZA Haut Bois, F-56580 Brehan, France.

${ }^{3}$ Amadeite SAS, Pole Biotechnol Haut Bois, F-56580 Brehan, France.

${ }^{4}$ IFREMER, Lab BIORAFhe, Rue lle Yeu,BP 21105, F-44311 Nantes 03, France.

${ }^{5}$ IDMer, 2 Rue Bateliere, F-56100 Lorient, France.

*Corresponding author : Kevin Hardouinemail address : kevin.hardouin.pro@gmail.com

\begin{abstract}
:
In order to develop innovative methods for the production of bioactive extracts with potential health benefits, enzyme-assisted extraction has been applied for the bioconversion of Ulva armoricana (Ulvales, Ulvophyceae). The extraction yields, chemical composition, the antioxidant and antiviral activities were determined to assess the efficiency of six commercial enzymatic preparations. Endoprotease treatments significantly increased the extraction yields compared to the control. The organic matter, neutral sugar and protein contents were increased in all extracts compared to an extraction with water, up to 2.0 -fold, 2.7 -fold and 1.75-fold, respectively. The samples prepared by a multiple-mix of glycosyl-hydrolases and an exo- $\beta-1,3(4)$-glucanase revealed activities against herpes simplex virus type- 1 at the median effective concentration $\left(E_{50}\right)$ of $373.0 \pm 20.7$ and $320.9 \pm 33.6 \mu \mathrm{g} / \mathrm{ml}$, respectively. These activities were correlated to high amounts of rhamnose, uronic acids and sulfate groups which are the main constituents of ulvans. Free radical scavenging capacity at medium inhibition concentrations $\left(\mathrm{IC}_{50}\right)$ of 1.8 and $12.5 \mathrm{mg} / \mathrm{ml}$ was shown for the extracts produced with endo-protease treatments and $6.0 \mathrm{mg} / \mathrm{ml}$ for the sample resulting from the extraction with the multiple-mix of glycosylhydrolases. This study reports the antiviral and antioxidant activities of Ulva armoricana extracts produced by enzyme-assisted extraction.
\end{abstract}

Keywords : Ulvan, Antiviral activity, Carbohydrate, Endo-protease, Bioconversion, Biorefinery 


\section{Introduction}

50

51 Macroalgal blooms occur worldwide, mainly caused by species from the phyla

52 Rhodophyta [1] and Chlorophyta [2], but the most widespread are caused by the

53 Chlorophyta species, such as those within the genus Ulva Linnaeus [3]. During the last

54 few decades, the coasts of Brittany (France) have suffered from significant green tides

55 mainly constituted of non-attached populations of Ulva armoricana and Ulva rotundata

56 (Ulvophyceae) [2]. Many studies have addressed the ecological and environmental

57 consequences of green tides which include uncoupled biogeochemical cycles, decreased water transparency, degradation of the intertidal environment, reduced biodiversity, hypoxia or anoxia, destruction of the marine coastal habitat (e.g., seagrass beds) and economic losses to marine industries [3]. However, these seaweed beachings also represent a huge algal biomass which could be exploited, for applications as plant elicitors, in animal health and in feed $[4,5,6]$. At this time, harvesting of these seaweeds remains the most cost-effective way to obtain a high tonnage of biomass. However, as the resource is unpredictable, aquaculture can

65 be an alternative in order to ensure its availability and improve the quality and homogeneity of the resource.

67 Over the last few years, there has been more investigations in the research into new bioactive natural molecules and valuable metabolites from seaweeds having an economic impact [4,7]. Several biological activities such as antiviral [6], antibacterial [8], antioxidant [9], anticoagulant [10] and antitumoral [11] have been identified in red (Rhodophyta) and brown (Phaeophyta) algae but few studies have been reported on 
green algae (Chlorophyta). Therefore, the production of bioactive extracts could represent a potential application for the valorization of algal blooms.

The algal cell wall is composed of two main classes of polysaccharides: (1) cellulose, hemicelluloses, mannans and xylans which constitute the skeleton and (2) a speciesspecific matrix phase of water soluble polysaccharides $[12,13]$. In Ulva sp., the matrix phase contains ulvans composed of sulfated (sulfation $17 \%$ ) xyloarabinogalactans and sulfated (sulfation $22 \%$ ) glucuronoxylorhamnans containing $20 \%$ of uronic acids $[14,15]$. Lahaye and Robic [13] proposed that the two major repeating disaccharides of the glucuronoxylorhamnans are aldobiuronic acids designated as type A: ulvanobiuronic acid 3-sulfate (A3s) and type B: ulvanobiuronic acid 3-sulfate (B3s). Partially sulfated xylose residues at $\mathrm{O}-2$ can also occur in place of uronic acids. In addition, glucuronic acid can branch at O-2 of rhamnose 3-sulfate [15].

Traditionally, hot water, acids, bases, organic solvents or ultrasounds were used to extract molecules from most bioresources; however, the enzymatic hydrolysis, an effective and nontoxic procedure, is currently applied in various industrial applications. Manufactured proteases are used in animal feed to improve the digestibility of proteins and in the detergent industries. Glycosyl hydrolases are applied in food/vegetable and starch processing, brewing, paper and pulp industries.

For the biorefinery of macroalgae, there is a trend to isolate new specific enzymes from marine organisms, for the degradation of polysaccharides, like ulvan-lyases, glucuronan-lyases, laminarinases, agarases, carrageenases or porphyranases [16]. These enzymes have been isolated and produced at laboratory scales but they are not yet available for industrial purposes. In this study, in order to develop an industrially applicable technology, commercial enzymatic preparations have been selected. 
96 Enzyme-based processes, using non-selective enzymes, have already been applied for

97 the production of bioactive extracts from macroalgae. Anticoagulant activities,

98

99 antioxidant capacity and immunomodulation properties have been highlighted in

enzymatic extracts of green, brown and red seaweeds, respectively [17].

The aim of this work was to evaluate six non-selective commercial enzymatic

preparations, two proteases and four carbohydrases as tools for improving the extraction efficiency and producing bioactive fractions from the French green seaweed $U$.

armoricana. The extracts were characterized by their respective biochemical

composition. Antiviral and antiradical activities were studied on both crude extracts and their isolated polysaccharide fractions.

\section{Material and Methods}

\subsection{Materials}

Algal sample: Ulva armoricana (Ulvales, Ulvophyceae) was collected on the beach in Plestin-les-Grèves (48³9'28" N, 3³7'47" W), English Channel (Brittany, France), on June $18^{\text {th }}, 2012$. Algae were then washed with tap water, ground and frozen at $-25^{\circ} \mathrm{C}$.

Enzymes: Six commercial enzymatic preparations, provided by Novozymes (Bagsværd, Denmark), were used for the hydrolysis of seaweed, a neutral endo-protease (P1, EC 3.4.24.28), a mix of neutral and alkaline endo-proteases (P2, EC 3.4.24.28/EC 3.4.21.62), a multiple-mix of carbohydrases (C1, EC 3.2.1.6/EC 3.2.1.8/EC 3.2.1.4/ EC 3.1.1.73), a mix of endo-1,4- $\beta$-xylanase/endo-1,3(4)- $\beta$-glucanase (C2, EC 3.2.1.8/EC 3.2.1.6), a cellulase (C3, EC 3.2.1.4) and an exo- $\beta-1,3(4)$-glucanase $(C 4,3.2 .1 .58)$. The 
120 EAE were compared to a control (Blank), treated in the same conditions and without enzyme. The blank corresponds to a classical water extraction at $50^{\circ} \mathrm{C}$ for $3 \mathrm{~h}$.

\subsection{Enzyme-Assisted Extraction}

Extractions were performed in a bioreactor in which $500.0 \mathrm{~g}$ of crushed algae $(8.3 \%$ dry matter, $d m$ ) and $500.0 \mathrm{~g}$ of Milli-Q water were mixed. The enzyme preparations ( $6 \%$ weight/dry weight, $w / d w$ ) were added to the algae and allowed to react during $3 \mathrm{~h}$ at $50^{\circ} \mathrm{C}$ followed by denaturation at $90^{\circ} \mathrm{C}$ for $15 \mathrm{~min}$. The $\mathrm{pH}$ of the reaction ranged from 6.2 at the beginning of the reaction to 5.9 at the end. After extraction, the samples were filtered, on a Buchner system using a synthetic cloth, and then centrifuged $(8,000 \mathrm{~g})$ for $20 \mathrm{~min}$ at $20^{\circ} \mathrm{C}$. In the end, two fractions were obtained, a soluble extract and an insoluble pellet. All samples were then freeze-dried and stored at $4^{\circ} \mathrm{C}$. Every extract consisted of the addition of the filtered soluble fraction plus the residual soluble fraction retained in the pellet.

The addition of dry matter, proteins, carbohydrates etc. due to the addition of the enzymatic preparations have been taken into account in the calculation both of extraction yields and biochemical composition of the hydrolyzates.

\subsection{Biochemical analyses}

An aliquot of dried seaweed $(10.0 \mathrm{mg})$ was hydrolysed for $2 \mathrm{~h}$ at $100^{\circ} \mathrm{C}$ with $1 \mathrm{M}$ hydrochloric acid $(1.0 \mathrm{ml})$ for the characterization of the raw material and then neutralized with $1 \mathrm{M}$ sodium hydroxide $(1.0 \mathrm{ml})$. The methods used for the biochemical 
analyses were the phenol sulfuric acid method of Dubois for neutral sugars, the metahydroxy-di-phenyl (MHDP) method for uronic acids, the Azure A method for sulfate groups and the bicinchinonic acid (BCA) protein assay kit for total proteins. All these methods are described and detailed in Hardouin et al. [18]. The total phenolic content was quantified by spectrophotometry according to the Folin Ciocalteu method [19] with minor modifications. One milliliter aliquot of extract solution (concentration range from 1 to $5 \mathrm{mg} / \mathrm{ml}$ ) was mixed with $5 \mathrm{ml}$ of Folin Ciocalteu reagent (10\% in distilled water).

After $5 \mathrm{~min}, 4 \mathrm{ml}$ of sodium carbonate ( $7.5 \%$ in distilled water) were added. The samples were incubated for $2 \mathrm{~h}$ at room temperature in darkness. The absorbance was measured at $760 \mathrm{~nm}$. A standard curve with serial gallic acid solutions ( 0 to $500 \mu \mathrm{g} / \mathrm{ml}$ ) was used for calibration. Results were expressed as g gallic acid equivalents (GAE) per $\mathrm{kg}$ of extract.

\subsection{Amino acids composition}

The total amino acid composition of freeze-dried extracts was determined after hydrolysis in $6 \mathrm{M} \mathrm{HCl}$ at $118^{\circ} \mathrm{C}$ for $18 \mathrm{~h}$. The hydrolyzed samples were completely dried under a nitrogen atmosphere and diluted by adding $2.5 \mathrm{ml}$ of water. The amino acid samples were prepared according to the EZ faast ${ }^{\mathrm{TM}}$ (Phenomenex, Torrance, California, U.S.A) procedure consisting of a solid phase extraction step followed by derivatization and liquid/liquid extraction. The amino acid samples were analyzed on an autosystem Gas chromatography-Flame ionization detection (Perkin Elmer, France; GC-FID) system composed of a Zebron ZB-AAA GC column (10 m x $0.25 \mathrm{~mm}$, 
separated using the following program: $110^{\circ} \mathrm{C}$ to $320^{\circ} \mathrm{C}$ (increase of $32^{\circ} \mathrm{C} / \mathrm{min}$ ). The detector was at $320^{\circ} \mathrm{C}$ and the gas pressure at 1.7 bar. The signals were registered using the Galaxie software (Varian, CA, USA). The amino acids were quantified by their response factor relative to the internal standard Norvaline added at a concentration of $200 \mu \mathrm{mol} / 1$.

\subsection{Sugar composition}

The composition of unitary sugars present in the polysaccharide chains was determined by High Pressure Anion Exchange Chromatography (Dionex). Prior to analyses, $1.0 \mathrm{ml}$ $\left(2 \mathrm{mg} / \mathrm{ml}\right.$ ) samples were hydrolysed for $48 \mathrm{~h}$ at $100^{\circ} \mathrm{C}$ with $110 \mu \mathrm{l}$ of $1 \mathrm{M}$ hydrochloric acid in a sealed glass tube. Before filtration, the samples were neutralized with $1 \mathrm{M}$ sodium hydroxide. $30 \mu 1$ were injected on an analytical column (CarboPac PA1, 4 x 250 $\mathrm{mm}$ ) with elution, at $1 \mathrm{ml} / \mathrm{min}$ and 110 bars, performed in alkaline conditions. Solution A consisted of Milli-Q water; solution B was $0.1 \mathrm{M}$ sodium hydroxide and solution $\mathrm{C}$ was $1 \mathrm{M}$ sodium acetate/0.1 M sodium hydroxide. The elution program corresponded to: 20 min isocratic conditions (solution $\mathrm{A} /$ solution $\mathrm{B}, 80: 20$ ), linear gradient (solution $\mathrm{C} 100 \%, 0$ to $5 \mathrm{~min}$ ), $5 \mathrm{~min}$ isocratic conditions (solution C, $100 \%$ ) and $20 \mathrm{~min}$ isocratic conditions (solution A/solution B, 80:20). Sugars were detected by pulsed amperometry with a detector composed of a silver standard electrode and a gold working electrode. The chromatograms were treated using Chromeleon ${ }^{\circledR}$ software provided by Dionex. Carbohydrates were identified and quantified by using calibration curves of standards composed of ribose, glucose, rhamnose, galactose, arabinose, xylose, mannose, fructose, guloheptose and glucuronic acid. 


\subsection{Polysaccharides molecular weight (Mw) distribution}

194

The polysaccharide molecular weight $(M w)$ distribution was determined by High

Performance Steric Exclusion Chromatography (HPSEC). The analytical chain was composed of an auto sampler (ASI 100, Dionex), an analytical pump (P680, Dionex) and two detectors connected in series, a UV detector set at $280 \mathrm{~nm}$ (UVD 400, Dionex) and a refractometer (Iota 2, Precision Instrument). Samples were prepared at $1.0 \mathrm{mg} / \mathrm{ml}$ in the eluent and filtered at $0.45 \mu \mathrm{m}$. The separation system consisted of a TSKgel ${ }^{\circledR}$

GMPW standard Guard Column (TOSOH) and a TSKgel ${ }^{\circledR}$ GMPW XL column (TOSOH $300 \times 7.8 \mathrm{~mm}, 13 \mu \mathrm{m})$. Elution was carried out at $30^{\circ} \mathrm{C}$, by using $0.1 \mathrm{M}$ sodium nitrate $\left(\mathrm{NaNO}_{3}\right)$ at a flow rate of $0.5 \mathrm{ml} / \mathrm{min}$. Dextran standards with molecular weights of 5.3 $\mathrm{kDa}, 17.9 \mathrm{kDa}, 129 \mathrm{kDa}$ and $636.4 \mathrm{kDa}, 1 \%(w: v)$, were used for calibration. Sodium chloride $(\mathrm{NaCl})$ was used to determine the maximum retention time (total volume, $\mathrm{V}_{\mathrm{t}}$ ) of the column.

\subsection{Polysaccharide isolation}

209

The isolation of polysaccharides was performed by ethanol precipitation. $450 \mathrm{ml}$ of ethanol were added to $50 \mathrm{ml}$ of extract and stored at $4^{\circ} \mathrm{C}$ over-night. Precipitates were recovered by centrifugation $(8,000 \mathrm{~g})$ at $4^{\circ} \mathrm{C}$ for $20 \mathrm{~min}$, washed twice with cold ethanol and freeze-dried. 
217 In vitro antiviral and cytotoxicity evaluation by cell viability: The in vitro antiviral and

218 cytotoxicity evaluation were performed according to the method used by Hardouin et al.

219 [18] on the model Vero cells and Herpes simplex virus-type 1 (HSV-1).

220 DPPH free radical scavenging assays: The antiradical activities of extracts were

221 measured with the 2,2-diphenyl-1-picrylhydrazyl (DPPH) method [20]. A solution of

222 DPPH was prepared at $0.25 \mathrm{mM}(0.1 \mathrm{~g} / \mathrm{l})$ by diluting $10 \mathrm{mg}$ of DPPH in $100 \mathrm{ml}$ of

223 methanol. Butylated hydroxyanisol (BHA) and butylated hydroxytoluene (BHT) were

224 used as standards (2 to $50 \mu \mathrm{g} / \mathrm{ml}$ ). The samples were dissolved in water at 1, 5, 12.5 and

$22525 \mathrm{mg} / \mathrm{ml}$ and aliquots of $1 \mathrm{ml}$ were mixed with $1 \mathrm{ml}$ of DPPH reagent. The samples

226 were incubated for $30 \mathrm{~min}$ at $40^{\circ} \mathrm{C}$ and the OD measured at $517 \mathrm{~nm}$ was compared to a

227 blank of methanol and water. The inhibitory concentration (scavenging) was calculated

228 by the formula: Scavenging $(\%)=\left[\left(\mathrm{OD}_{\text {control }}-\mathrm{OD}_{\text {sample }}\right) / \mathrm{OD}\right.$ control $] \times 100$. The $\mathrm{IC}_{50}$

229 was determined with the curve and correspond to $50 \%$ inhibition.

\subsection{Statistical analysis}

232

233 Results are expressed as means \pm standard deviation $(\mathrm{SD})(\mathrm{n}=3)$. The statistical analysis was carried out on SPSS (IBM, Armonk, NY, USA) using the one-way analysis of variance (ANOVA) followed by a Duncan test at the $5 \%$ level $(\mathrm{p}<0.05)$ to evaluate differences between the samples. For each series of values, the significant differences are labelled by superscript letter.

\section{Results and discussion}




\subsection{Characterization of the Ulva armoricana raw sample}

Ulva armoricana samples contained $15.9 \pm 1.2 \%$ ash, $23.4 \pm 1.4 \%$ neutral sugars, 21.1

$244 \pm 0.1 \%$ uronic acids, $24.4 \pm 0.1 \%$ proteins, $4.0 \pm 0.1 \%$ total nitrogen, $20.9 \pm 0.9 \%$ sulfate groups, $0.6 \pm 0.1 \%$ of total phenolic compounds and $0.6 \pm 0.0 \%$ lipids. The total carbohydrate content ( $64.4 \%)$ was calculated by the addition of neutral sugars, sulfate groups and uronic acids values. Lipids and phenolic compounds represented a very small part of the algal composition. These levels are in agreement with those reported by Holdt and Kraan [7] for the genus Ulva sp. This composition also confirmed that polysaccharides are the main constituent of the Ulva sp. thallus. The respective contents of each metabolite in algae vary greatly depending on season, state of growth, geographical area and environment quality [21].

\subsection{Enzymatic hydrolysis yields}

Figure 1 shows the amount of dry matter in the extracts, expressed as a percentage of the total seaweed dry weight ( $\%$ total $d w)$. The proportion of the dry matter solubilized by grinding and incubation was estimated by the blank at $44.3 \pm 0.5 \%$ of the initial yields, $44.9 \pm 1.7 \%$ for $\mathrm{C} 1,44.6 \pm 0.6 \%$ for $\mathrm{C} 2,45.1 \pm 2.7 \%$ for $\mathrm{C} 3$, were not significantly different from the blank and show that enzymes $\mathrm{C} 1$ (mix of carbohydrases), C2 (endo-1,4- $\beta$-xylanase/endo-1,3(4)- $\beta$-glucanase) and C3 (endo-1,4- $\beta$ - 
glucanase) did not improve the extraction. The enzymes C4 (exo-1,3(4)- $\beta$-glucanase),

P1 (neutral endo-protease) and P2 (neutral and alkaline endo-proteases) induced a $70.7 \pm 1.1 \%, 76.7 \pm 0.8 \%$ and $88.4 \pm 0.2 \%$, respectively. These three enzymes provided an extraction gain of $60 \%, 73 \%$ and $100 \%$, respectively, compared to the control (blank).

Previous studies have reported the extraction of water-soluble compounds from the chemical nature of the isolated compounds are greatly dependent on the extraction procedures.

274 Aqueous and chemical extractions were applied in order to produce fractions enriched in different metabolites. Co-extraction of the water-soluble polysaccharides (ulvans and glucuronans), using oxalate solution at $85^{\circ} \mathrm{C}$, led to an $8-29 \%$ extraction yield for Ulva sp. [12,13,22]. Xyloglucans and glucuronans, two minor parietal polysaccharides, have also been reported to be selectively isolated in an alkali-soluble phase $[13,14]$.

The application of a basic $(0.1 \mathrm{M} \mathrm{NaOH})$ solution containing $\beta$-mercaptoethanol produced the highest protein yield for the species Ulva rigida and Ulva rotundata [22]. In this latter study, the use of enzymatic preparations (cellulase and polysaccharidases mixture) appeared to be less efficient than aqueous solutions procedures. In this work, the lack of effect of the three carbohydrase preparations $\mathrm{C} 1, \mathrm{C} 2$ and $\mathrm{C} 3$ agrees with data observed by Fleurence et al. [22]. The enzymatic preparation C4 has been reported to exhibit a proteolytic side-activity [25] that may explain the improved yield, only slightly below those of the proteases. This is the first report of enzymatic degradation of Ulva sp. using proteases. The high efficiency of the proteolytic activities can be explained by 
the ubiquitous nature of proteins and illustrates the importance of proteins for the integrity of the cell wall.

Finally, the nature of enzymatic activity greatly influenced the extraction yields which are higher than those obtained by chemical methods [26,27]. According to these results, enzymes can be classified in two categories: enzyme preparations $\mathrm{C} 1, \mathrm{C} 2, \mathrm{C} 3$, which have low efficiencies and enzyme preparations $\mathrm{C} 4, \mathrm{P} 1$ and $\mathrm{P} 2$ which have a higher extraction power. These last three enzymatic preparations are also more efficient than classical water and chemical methods. The selectivity of the enzyme-assisted extraction was assessed by the characterization of the biochemical composition.

\subsection{Biochemical characterization of crude enzymatic extracts}

Table I shows the biochemical composition of extracts, after deducting the input from the enzymatic preparations. The biochemical composition is expressed as the percentage in the dry hydrolyzates and by the absolute weights $(\mathrm{g})$ solubilized by the process. The ash contents $(\% d w)$ ranged between $16.7 \pm 2.1$ and $18.6 \pm 2.1$ and were consistent with the content found in the raw material. These levels correspond to the inorganic part of the seaweed. They were increased in samples C4, P1 and P2 with a good correlation with the extraction yields. The same trend was observed for total phenolic compounds, indicating that the extraction of non-structural components (ash, total phenols) is correlated with the extraction yields with no apparent effect of the extraction procedure. The neutral sugars contents were higher in samples $\mathrm{C} 1$ and $\mathrm{C} 3,18.4 \pm 0.8$ and $18.3 \pm$ $3.3 \% d w$, respectively. Conversely, the blank and the extract $\mathrm{C} 2$ contained the lowest amounts, respectively $9.0 \pm 1.2$ and $8.1 \pm 1.6 \% d w$. Meanwhile, the extracts obtained 
312 from the enzymes C4, P1 and P2 contain intermediate contents between $11.3 \pm 2.3$ and $31314.7 \pm 0.5 \% d w$. However, the absolute amount of neutral sugars solubilized by these

314 three enzymes is higher with respectively $3.7 \pm 0.2,4.1 \pm 0.2$ and $3.7 \pm 0.8 \mathrm{~g}$. The

315 neutral sugars contents were lower than those determined after chemical extraction

316 methods from Ulva clathrata [27] and after aqueous extraction from Ulva rotundata

$317[26]$.

318 The blank, C2 and P1 contained the highest protein concentrations with $9.4 \pm 0.4,8.8 \pm$

3190.9 and $10.1 \pm 0.3 \% d w$ respectively, but the highest total protein weights were observed in samples C4 $(2.2 \pm 0.1 \mathrm{~g}), \mathrm{P} 1(2.8 \pm 0.1 \mathrm{~g})$ and P2 $(2.1 \pm .0 .1 \mathrm{~g})$. The increase in total protein weights of these samples is directly correlated with the increase in extraction yields.

From all extracts, samples $\mathrm{C} 1$ and $\mathrm{C} 3$ containing $53.7 \%$ and $55.6 \% d w$ of total carbohydrates (neutral sugars, uronic acids and sulfate groups), respectively, were the most concentrated. On the opposite, the samples C4, P1 and P2 contained the lowest concentrations, $46 \%, 46 \%$ and $36 \% d w$, respectively. Enzymatic preparations $\mathrm{C} 1$ and C3 appear to be the most selective for the extraction of total carbohydrates. However, due to the significant increase in extraction yields, enzymes C4, P1 and P2 solubilized a larger amount $(\mathrm{g})$ of total sugars and protein, and are the most efficient. The proteolytic side-activity of the enzymatic preparation $\mathrm{C} 4$ [25] is confirmed by the selective extraction of proteins.

332 Due to the mainly polysaccharidic nature of the cell wall of $U$. armoricana, these results may seem paradoxical, but they confirm that non-selective industrial carbohydrases do not hydrolyze the matricial polysaccharides of the seaweed cell wall and therefore do not improve the extraction of seaweed components. Conversely, to explain the efficient 
effect of proteases on seaweeds, the first assumption is that proteases have a destabilizing effect on the cell wall, which causes the release and solubilization of a higher amount of compounds. These results also suggest that proteins are attached to polysaccharides and act as a cement in the structure of the cell wall [13]. However, there is a second hypothesis which is that proteases hydrolyze the membrane cell proteins causing a release of intracellular material and not exclusively molecules from the seaweed cell wall.

\subsection{Amino acid composition of extracts}

Gas chromatography-Flame ionization detection (GC-FID) was used to identify and quantify 16 amino acids (AA). Cysteine, arginine and tryptophan were not determined by this method and glutamine and asparagine were quantified as glutamic and aspartic acids, respectively. The results were expressed as a percentage of the total AA measured. The average rates of AA released in the extracts are given in Table II. The characterization of the AA profile revealed minor differences between extracts. AA can be divided into three categories according to their content in samples, high $(<10 \%)$, medium (3-10\%) and low (> $3 \%)$.

These results provided information on the protein composition of the algae. Four AAs were identified as major, alanine, glycine, aspartic acid and glutamic acid as they constituted more than $10 \%$ of the extracted proteins. Methionine, hydroxyproline, lysine, histidine and tyrosine were present in very small amounts, ranging from 0.9 to $2.9 \%$. The content of the remaining AAs was average, between 3 and $10 \%$. Although the composition of the samples was quite similar, there were still some differences 
against the blank. The alanine content was between $12.1 \%$ and $14.1 \%$ against $16.3 \%$ in the blank. The results were similar for glycine with rates between $8.7 \%$ and $9.1 \%$ in the extracts against $11.1 \%$ in the control. The trend was reversed for glutamic acid and aspartic acid as their rates in the negative control, $8.1 \%$ and $11.1 \%$ respectively, were lower than in the extracts, 9.3 to $14.3 \%$ and 12.9 to $14.5 \%$, respectively. No difference appeared between extracts and the blank for the other AAs. Therefore, due to the differences in the amounts of several amino acids, the proteins solubilized by the enzymatic treatment seem to have a different composition from those solubilized by incubation in water. The nature of the enzymatic preparation did not affect the amino acid profile of the extracts.

These results matched with those obtained by Fleurence et al. [28], who had shown the enriched composition, in alanine $(5.51-7.01 \%$ proteins $)$, glycine $(6.34-7.53 \%$ proteins), aspartic acid (6.09- $11.84 \%$ proteins $)$ and glutamic acid $(11.70-23.35 \%$ proteins), of proteins from U. armoricana collected in October 1997. However, some slight differences appear in the respective amino acids contents. These differences could be due to the seasonal variability and the life cycle of seaweed which do not produce the same types of proteins during the year. These differences could also be explained by the extraction method used. Thus, enzyme-assisted extraction might selectively extract different types of protein. The seasonal variability of the proteins and amino acids composition was also highlighted by Fleurence et al. [28].

\subsection{Sugar composition}


The results from the compositional analyzes of carbohydrates by High Pressure Anion

384 Exchange Chromatography (HPAEC) are given in Table III. Values represent the mean

385 of the percentage of the different sugars relative to the total carbohydrate content

$386(\mathrm{~g} / 100 \mathrm{~g}$ total carbohydrate). Fructose and ribose were identified in very low

387 concentration $(<3 \%$ total sugars) while some unidentified and minor carbohydrates are

388 included in 'other sugars'. Two unidentified and charged carbohydrates were added to

389 uronic acids (UAc) due to their retention time, close to the glucuronic acid. These were

390 probably galacturonic and iduronic acids [13].

391 Analyzes showed the predominance of glucose, rhamnose and uronic acids. Lahaye and

392 Robic [13] described the composition of ulvans and showed that it is composed mainly

393 of rhamnose $(16.8-45.0 \% d w)$, xylose $(2.1-12.0 \%)$, glucose $(0.5-6.4 \%)$, uronic

394 acid $(6.5-19.0 \%)$, and sulfate groups $(16.0-23.2 \%)$. The results obtained in our study

395 correspond to these values and show the presence of ulvans in the extracts. Lahaye and

396 Robic [13] also reported the presence of $\beta$-glucans, polymers of glucose, which could

397 explain the high levels of glucose in crude samples (Table III a).

398 The isolation step aimed to selectively separate the polysaccharide fractions from the extracts. The sugar compositions of these fractions (Table III b) differed from those of the crude hydrolyzates. The precipitation led to a decrease of the glucose amounts in all samples, highly amplified (-47 to $-72 \%$ ) in $\mathrm{C}_{p}, \mathrm{C} 2_{p}, \mathrm{C} 3_{p}$, and $\mathrm{C}_{p}$. The isolation also corresponded to a high increase in the rhamnose and uronic acids contents in the same 403 samples. These variations were lower in the blank and in samples $\mathrm{P} 1_{p}$ and $\mathrm{P} 2_{p}$. These results suggest that the proteases and the control led to the solubilization of neutral ( $\beta$-glucans) and matricial (ulvans) carbohydrates in their native forms, without degradation. Regarding the loss of glucose after precipitation, $\beta$-glucans might be 

oligosaccharides and in monosaccharides which were not precipitated, while the ulvans

409

410 were recovered in their native forms. Combined with the extraction yields, these results show that carbohydrases have a selective action on the glucans of the U. armoricana cell wall, without improving the efficiency of the extraction, whereas proteases, which were more efficient, solubilized native carbohydrates.

The samples obtained with the enzymatic preparation $\mathrm{C} 4$, which was one of the most efficient enzyme mixtures, show a decrease in glucose and an increase in rhamnose and uronic acid contents, confirming the simultaneous effect of the $\beta$-glucanase and the protease previously observed in this study.

\subsection{Polysaccharides molecular weight (Mw) distribution}

The molecular weight distribution of poly- and oligosaccharides in extracts has been determined by High Performance Steric Exclusion Chromatography (HPSEC). Figure 2 is a representative example of the chromatograms obtained for the different samples, comparing the samples $\mathrm{C} 4$ and $\mathrm{C}_{p}$, respectively, before and after ethanol precipitation.

The dotted line represents the crude extract $\mathrm{C} 4$ and the solid line the polysaccharide fraction $\mathrm{C}_{p}$. The figure shows four peaks in $\mathrm{C} 4$ and three in $\mathrm{C} 4_{p}$. The last peak (C4) was the total volume of the column and corresponded to salts. This peak does not appear on chromatogram $\mathrm{C}_{p}$, confirming that salts and monosaccharides were eliminated by the precipitation. The high mass polysaccharide fractions increased in isolated samples while the low mass polysaccharides decreased. These results confirmed the efficiency of ethanol precipitation for the isolation of polysaccharides. 
431 Chromatograms also show that there were two groups of polysaccharides, with average

432

433

434

435

436

437

438

439

440

441

442

443

444

445

446

447

448

449

450

451

452

453

454

molecular weights of 2,000 kDa and $600 \mathrm{kDa}$, and a group of oligosaccharides $(3 \mathrm{kDa})$.

The two groups of polysaccharides confirmed the presence of ulvans in samples and

correspond to the results reported by Robic et al. [29] describing the structure of ulvans.

The same study also described the molecular weights of ulvans ranging from 300 to 500

$\mathrm{kDa}$ for the first group and from 140 to $180 \mathrm{kDa}$ for the second group. These values are below those obtained in our study. This difference may be due to the extraction method or HPSEC conditions. In their study, Robic et al. [29] used water extraction in sodium oxalate at $85^{\circ} \mathrm{C}$ for $2 \mathrm{~h}$, which is described as the optimal condition for ulvan extraction. The increase of polysaccharides and the corresponding carbohydrate compositions confirm the enrichment in ulvans in the isolated fractions.

\subsection{Screening of in vitro antiviral activity by cell viability of extracts}

The crude extracts and the isolated polysaccharide fractions were tested in vitro for their cytotoxicity on Vero cells and their antiviral activity against herpes simplex virus type-1 (Table IV).

Acyclovir, used as reference molecule, presented an effective concentration $\left(\mathrm{EC}_{50}\right)$ of $0.3 \mu \mathrm{g} / \mathrm{ml}$ and a cytotoxicity $\left(\mathrm{CC}_{50}\right)$ above $500 \mu \mathrm{g} / \mathrm{ml}$. No crude extracts exhibited cytotoxic effect to Vero cells for concentrations up to $500.0 \mu \mathrm{g} / \mathrm{ml}$. The microscopic examination and the assessment of cell viability showed that all cells were viable after $72 \mathrm{~h}$ of contact with the extracts at MOI 0.001 . The crude extracts did not show activity against the virus for concentrations under $500.0 \mu \mathrm{g} / \mathrm{ml}$. After isolation, the polysaccharide fractions still did not show cytotoxic activity. $\mathrm{C}_{p}$ and $\mathrm{C} 4_{p}$ fractions 
exhibited activities against $\mathrm{HSV}-1$ with a respective $\mathrm{EC}_{50}$ of $373.0 \pm 20.7 \mu \mathrm{g} / \mathrm{ml}$ and $320.9 \pm 33.6 \mu \mathrm{g} / \mathrm{ml}$. The polysaccharides obtained from other extracts did not show activity in the range of concentration.

The antiviral activity of the samples $\mathrm{C} 1_{p}$ and $\mathrm{C} 4_{p}$ is correlated to the high amounts of rhamnose, the main component of ulvans, coupled with a higher purity. The antiviral activity of sulfated polysaccharides from seaweed had already been shown in previous studies $[6,30]$. However, the $\mathrm{EC}_{50}$ are higher than those obtained for other sulfated polysaccharides.

This work is the first reporting the antiviral activity of enzyme-assisted extracts containing ulvans from U. armoricana. For many years, there has been an increasing demand from the pharmaceutical industry for the discovery of new antiviral molecules. The huge Ulva sp. biomass might therefore respond to this demand [6].

\subsection{DPPH scavenging - Antiradical activity}

The free radical scavenging of the blank and the enzymatic extracts of Ulva armoricana was estimated by the decrease in absorbance due to the reduction of the DPPH radical by the extracts (Table IV). The standards BHA and BHT present an inhibiting concentration $\left(\mathrm{IC}_{50}\right)$ of 4.8 and $6.8 \mu \mathrm{g} / \mathrm{ml}$, respectively. Samples obtained with P1, C1 and $\mathrm{P} 2$ presented positive results with an $\mathrm{IC}_{50}$ of $1.8,6.0$ and $12.5 \mathrm{mg} / \mathrm{ml}$, respectively. The other samples did not have a significant antiradical effect in the concentration range used. As previously reported [31], the antioxidant power of the extract is generally

477 related to the presence of phenolic compounds in seaweed and/or seaweed extracts. Some studies also reported that sulfated polysaccharides (ulvans) could also have an 
479 antiradical effect [32]. According to the biochemical composition, the three bioactive 480 extracts are also the most concentrated in polyphenols, with respective concentrations of $481 \quad 0.8 \%, 0.6 \%$ and $1.0 \%$. Secondly, no significant differences appear, between these 482 samples and the others, in the ulvan content. Therefore, the antiradical activity could be 483 related to phenolic compounds but some further analyses, before and after specific purification, would need to be realized in order to confirm this hypothesis.

Despite its low levels of antioxidant compounds, Ulva armoricana could be an interesting and novel bioresource for these compounds. As with antiviral compounds, the pharmaceutical, cosmetic and food industries, which currently use mainly synthetic molecules, are constantly looking for new sources of natural sources of antiradical molecules. Antioxidant compounds are used in order to limit the organoleptic degradation of food, as anti-aging in cosmetics or as drugs in the treatment of oxidative stress $[9,18]$.

\section{Conclusion}

This study demonstrates the potential of Enzyme-Assisted Extraction for the valorization of Ulva sp. biomass. The improvement of extraction yields using proteases and the selective degradation of $\beta$-glucans using carbohydrases have been demonstrated. This is the first study reporting the efficiency of proteases for the liquefaction without degradation of Ulva armoricana components. These extraction procedures and the isolation step allowed the preparation of samples enriched in ulvans. Finally, the relationship between ulvans and antiviral activity has been established. 


\section{References}

504

505 [1] Schiel, D. R., Thompson, G. A., 2012. Demography and population biology of the 506 invasive kelp Undaria pinnatifida on shallow reefs in southern New Zealand. J. Exp. 507 Mar. Biol. Ecol. 434-435, 25-33.

508 [2] Coat, G., Dion, P., Noailles, M.-C., De Reviers, B., Fontaine, J.-M., Berger-Perrot, 509 Y., Loiseaux-De Goér, S., 1998. Ulva armoricana (Ulvales, Chlorophyta) from the 510 coasts of Brittany (France). II. Nuclear rDNA ITS sequence analysis. Eur. J. Phycol. 33, $51181-86$.

512 [3] Smetacek, V., Zingone, A., 2013. Green and golden seaweed tides on the rise. 513 Nature 504, 84-88.

514 [4] Cardozo, K.H.M., Guaratini, T., Barros, M.P., Falcão, V.R., Tonon, A.P., Lopes,

515 N.P., Campos, S., Torres, M.A., Souza, A.O., Colepicolo, P., Pinto, E., 2007.

516 Metabolites from algae with economical impact. Comp. Biochem. Phys. C. 146, 60-78.

517 [5] Harnedy, P.A., Fitzgerald, R.J., 2011. Bioactive proteins, peptides and amino acids 518 from macroalgae. J. Phycol. 47, 218-232.

519 [6] Wang, W., Wang, S.-X., Guan, H.-S., 2012. The Antiviral Activities and 520 Mechanisms of Marine Polysaccharides: An Overview. Marine Drugs 10, 2795-2816.

521 [7] Holdt, S.L., Kraan, S., 2011. Bioactive compounds in seaweed: functional food 522 applications and legislation. J. Appl. Phycol. 23, 543-597.

523 [8] Sridharan, M.C., Dhamotharan, R., 2012. Antibacterial activity of marine brown 524 alga Turbinaria conoides. J. Chem. Pharm. Res. 4, 2292-2294.

525 [9] Heo, S.J., Park, E.J., Lee, K.W., Jeon, Y.J., 2005. Antioxidant activities of 526 enzymatic extracts from brown seaweeds. Biores. Technol. 96, 1613-1623. 
Mourão, P.A.S., 2005. Structure and anticoagulant activity of a sulfated galactan from the red alga, Gelidium crinale. Is there a specific structural requirement for the anticoagulant action? Carbohyd. Res. 340, 2015-2023.

[11] Harada, H., Noro, T., Kamei, Y., 1997. Selective antitumor activity in vitro from marine algae from Japan coasts. Biol. Pharm. Bull. 20, 541-546.

[12] Ficko-Blean, E., Hervé, C., Michel, G. 2015. Sweet and sour sugars from the sea: the biosynthesis and remodeling of sulfated cell wall polysaccharides from marine macroalgae. Perspectives in phycology, 2(1), 51-64.

[13] Lahaye, M., Robic, A., 2007. Structure and Functional Properties of Ulvan, a Polysaccharide from Green Seaweeds. Biomacromolecules 8, 1765-1774. glucans from the cell wall of the marine green alga Ulva lactuca (L.) Thuret. Carbohydr. Res. 262, 115-125.

[15] Ray, B., Lahaye, M., 1995. Cell-wall polysaccharides from the marine green alga

542 Ulva "rigida" (Ulvales, Chlorophyta). Chemical structure of ulvan. Carbohyd. Res. $274,313-318$.

[16] Michel, G., and Czjzek, M., 2013. Polysaccharide-degrading enzymes from marine bacteria, in Trincone, A., (Ed.), Marine Enzymes for Biocatalysis. Woodhead Publishing, 2013, pp. 429-464. ISSN 2050-0289.

547 [17] Hardouin, K., Bedoux, G., Burlot, A.S., Nyvall-Collén, P., Bourgougnon, N., 2014a. Enzymatic recovery of metabolites from seaweeds: potential applications, in:

549 Bourgougnon, N., (Ed.), Advances Botanical Research, Sea Plants, Volume 71. Elsevier 550 Ltd: 2014; pp. 281-323. ISSN 0065-2296. 
551 [18] Hardouin, K., Burlot, A.S., Bedoux, G., Nyvall-Collén, P., Bourgougnon, N., 552 2014b. Biochemical and antiviral activities of enzymatic hydrolyzates from different

553 invasive French seaweeds. J. Appl. Phycol. 26, 1029-1042.

554 [19] Turkmen, N., Sari, F., Velioglu, S., 2005. The effect of cooking methods on total 555 phenolics and antioxidant activity of selected green vegetables. Food Chem., 93, 713556718.

557 [20] Sánchez-Moreno, C., Larrauri, J.A., Saura-Calixto, F., 1998. A procedure to 558 measure the antiradical efficiency of polyphenols. J. Sci. Food Agric. 76, 270-276.

559 [21] Alves de Guimaraens, M., Coutinho, R., 2000. Temporal and spatial variation of 560 Ulva spp. and water properties in the Cabo Frio upwelling region of Brazil. Aquat. Bot. $56166,101-114$.

562 [22] Fleurence, J., Le Coeur, C., Mabeau, S., Maurice, M., Landrein, A., 1995.

563 Comparison of different extractive procedures for proteins from the edible seaweeds

564 Ulva rigida and Ulva rotundata. J. Appl. Phycol. 7, 577-582.

565 [23] Elboutachfaiti, R., Delattre, C., Petit, E., El Gadda, M., Courtois, B., Michaud, P., 566 EL Modafar, C., Courtois, J., 2009. Improved isolation of glucuronan from algae and 567 the production of glucuronic acid oligosaccharides using a glucuronan lyase. Carbohyd. 568 Res., 344, 1670-1675.

569 [24] Costa, C., Alves, A., Pinto, P.R., Sousa, R.A., Borges da Silva, E.A., Reis, R.L., 570 Rodrigues, A.E., 2012. Characterization of ulvan extract to assess the effect of different 571 steps in the extraction procedure. Carbohyd. Polym., 88, 537-546.

572 [25] Anderson, T. H., 2008. Assessment of DNA contents of soil fungi. Landbauforsch. 573 vti ag., 58, 19-28. 
574 [26] Robic, A., Sassi, J.F., Lahaye, M., 2008. Impact of stabilization treatments of the 575 green seaweed Ulva rotundata (Chlorophyta) on the extraction yield, the physico-

576 chemical and rheological properties of ulvan. Carboh. Polym., 74, 344-352.

577 [27] Hernandez-Garibay, E., Zertuche-Gonzalez, J.A., Paccheco-Ruiz, I., 2011.

578 Isolation and chemical characterization of algal polysaccharides from the green seaweed

579 Ulva clathrata (Roth) C. Agarddh. J. Appl. Phycol., 23, 537-542.

580 [28] Fleurence, J., Chenard, E., and Luçon, M. 1999. Determination of the nutritional

581 value of proteins obtained from Ulva armoricana. J. Appl. Phycol. 11, 231-239.

582 [29] Robic, A., Gaillard, C., Sassi, J.F., Lerat, Y., Lahaye, M. 2009. Ultrastructure of 583 ulvan: a polysaccharide from green seaweeds. Biopolymers. 91(8), 652-664.

584 [30] Aguilar-Briseno, J.A., Cruz-Suarez, L.E., Sassi, J.F., Ricque-Marie, D., Zapata585 Benavides, P., Mendoza-Gambosa, E., Rodriguez-Padilla, C., Trejo-Avila, L.M., 2015.

586 Sulphated polysaccharide from Ulva clathrata and Cladosiphon okamuranus seaweeds 587 both inhibit viral attachment/entry and cell-cell fusion, in NDV infection. Mar. Drugs, $588 \quad 13,697-712$.

589 [31] Tanniou, A., Serrano Leon, E., Laurent, V., Elena, I., Mendiola, J.A., Stéphane, C., 590 Nelly, K., Stéphane, L.B., Luc, M., Valérie, S.-P., 2013. Green improved processes to 591 extract bioactive phenolic compounds from brown macroalgae using Sargassum 592 muticum as model. Talanta 104, 44-52.

593 [32] Shao, P., Chen, M., Pei, Y., Sun, P., 2013. In intro antioxidant activities of 594 different sulfated polysaccharides from chlorophytan seaweeds Ulva fasciata. Int. J. 595 Biol. Macromol. 59, 293-300.

596

597 
599

600 Figure 1: Percent dry weight (\% total $d w)$ in extracts after the enzyme-assisted

601 extraction (EAE).

602 The respective enzymatic preparations inputs have been deducted from the dry samples.

603 Values are means \pm SD $(n=3)$. Values with different superscript letters are significantly

604 different $(\mathrm{p}<0.05)$. Proteases are indicated with black bars; Carbohydrases by grey

605 bars; Water extract by a white bar.

606 Blk: control, C1: multiple-mix of carbohydrases, C2: mix of endo-1,4- $\beta$-xylanase/endo-

607 1,3(4)- $\beta$-glucanase, C3: cellulase, C4: exo- $\beta$-1,3(4)-glucanase, P1: neutral endo-

608 protease, P2: mix of neutral and alkaline endo-proteases.

609

610 Figure 2: High pressure steric exclusion chromatogram (RI) of samples $\mathrm{C} 4$ and $\mathrm{C} 4_{p}$,

611 before and after ethanol precipitation.

612 Flow: 0.5 ml/min; Pressure: 9-13 bars; Eluent: 0.1 M NaNO3; Sample: $1 \mathrm{mg} / \mathrm{ml}$; Inject.

613 vol.: $100 \mu \mathrm{L}$, detection: refractive index. C4: dotted line; $\mathrm{C}_{p}$ : solid line.

614

615

616 
618

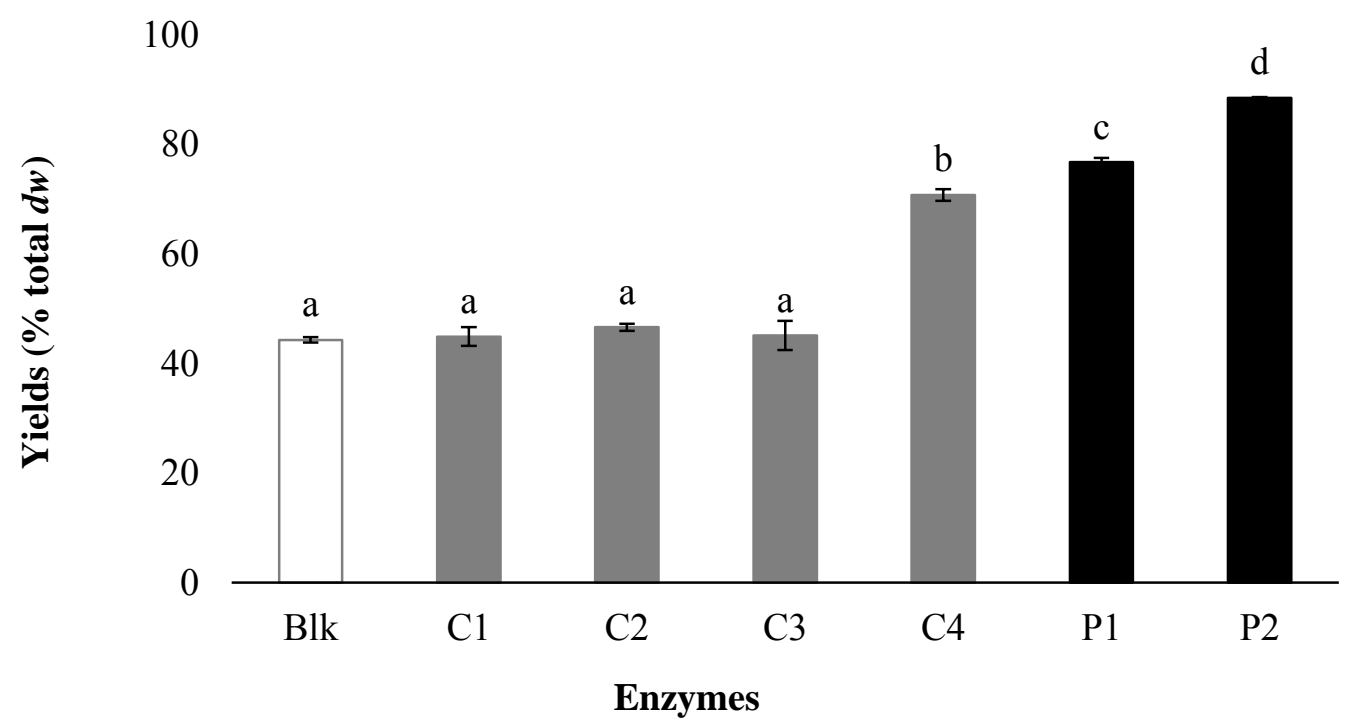

619

620 Figure 1: Percent dry weight (\% total $d w)$ in extracts after the enzyme-assisted

621 extraction (EAE).

622 The respective enzymatic preparations inputs have been deducted from the dry samples.

623 Values are means \pm SD $(n=3)$. Values with different superscript letters are significantly

624 different $(\mathrm{p}<0.05)$. Proteases are indicated with black bars; Carbohydrases by grey

625 bars; Water extract by a white bar.

626 Blk: control, C1: multiple-mix of carbohydrases, C2: mix of endo-1,4- $\beta$-xylanase/endo-

627 1,3(4)- $\beta$-glucanase, C3: cellulase, C4: exo- $\beta$-1,3(4)-glucanase, P1: neutral endo-

628 protease, P2: mix of neutral and alkaline endo-proteases.

629 
630 TABLE I: Biochemical composition of raw material and enzymatic extracts $(\% d w$ and

g).

632 Values are means \pm SD $(n=3)$. Values with different superscript letters are significantly 633 different $(\mathrm{p}<0.05)$. Organic matter was determined by the difference between the total 634 dry matter and the ash content.

\begin{tabular}{|c|c|c|c|c|c|c|c|c|}
\hline & & Ash & $\begin{array}{c}\text { Organic } \\
\text { matter }\end{array}$ & $\begin{array}{c}\text { Neutral } \\
\text { sugars }\end{array}$ & $\begin{array}{c}\text { Uronic } \\
\text { acids }\end{array}$ & Sulfate & Proteins & $\begin{array}{c}\text { Total } \\
\text { phenols }\end{array}$ \\
\hline \multirow{2}{*}{$\begin{array}{l}\text { Raw } \\
\text { algae }\end{array}$} & $\% d w$ & $15.9 \pm 1.2$ & $84.1 \pm 1.2$ & $23.2 \pm 1.4$ & $21.1 \pm 0.1$ & $20.1 \pm 0.9$ & $24.4 \pm 0.1$ & $0.6 \pm 0.1$ \\
\hline & $\mathrm{g}$ & $6.0 \pm 0.1$ & $31.5 \pm 0.4$ & $8.7 \pm 0.1$ & $7.9 \pm 0.1$ & $7.5 \pm 0.1$ & $9.2 \pm 0.1$ & $0.3 \pm 0.1$ \\
\hline \multirow[t]{2}{*}{ Blank } & $\% d w$ & $18.0 \pm 1.2^{\mathrm{a}}$ & $82.0 \pm 1.2^{\mathrm{a}}$ & $9.0 \pm 1.2^{\mathrm{a}}$ & $21.5 \pm 4.2^{\mathrm{e}}$ & $17.2 \pm 0.1^{\mathrm{d}}$ & $9.4 \pm 0.4^{\mathrm{cd}}$ & $0.5 \pm 0.0^{\mathrm{ab}}$ \\
\hline & $\mathrm{g}$ & $3.1 \pm 0.3^{\mathrm{a}}$ & $13.9 \pm 0.2^{\mathrm{a}}$ & $1.5 \pm 0.3^{\mathrm{a}}$ & $3.6 \pm 0.7^{\mathrm{bc}}$ & $2.9 \pm 0.1^{\mathrm{a}}$ & $1.6 \pm 0.1^{\mathrm{c}}$ & $0.1 \pm 0.0^{\mathrm{a}}$ \\
\hline \multirow[t]{2}{*}{ C1 } & $\% d w$ & $17.3 \pm 1.6^{a}$ & $82.7 \pm 1.6^{a}$ & $18.4 \pm 0.8^{d}$ & $16.2 \pm 0.9^{\mathrm{cd}}$ & $19.1 \pm 0.3^{\mathrm{e}}$ & $8.8 \pm 0.9^{c}$ & $0.7 \pm 0.2^{b}$ \\
\hline & $\mathrm{g}$ & $3.0 \pm 0.2^{\mathrm{a}}$ & $14.4 \pm 0.7^{\mathrm{a}}$ & $3.2 \pm 0.2^{\mathrm{b}}$ & $2.8 \pm 0.2^{\mathrm{b}}$ & $3.3 \pm 0.2^{\mathrm{c}}$ & $1.5 \pm 0.2^{\mathrm{c}}$ & $0.1 \pm 0.0^{\mathrm{a}}$ \\
\hline \multirow[t]{2}{*}{$\mathrm{C} 2$} & $\% d w$ & $17.0 \pm 2.7^{a}$ & $83.0 \pm 2.7^{a}$ & $8.1 \pm 1.6^{\mathrm{a}}$ & $10.9 \pm 1.3^{\mathrm{ab}}$ & $17.4 \pm 0.2^{\mathrm{d}}$ & $6.2 \pm 0.4^{\mathrm{a}}$ & $0.6 \pm 0.1^{\mathrm{ab}}$ \\
\hline & $\mathrm{g}$ & $2.8 \pm 0.6^{\mathrm{a}}$ & $13.9 \pm 0.2^{\mathrm{a}}$ & $1.4 \pm 0.6^{\mathrm{a}}$ & $1.8 \pm 0.2^{\mathrm{a}}$ & $2.9 \pm 0.1^{\mathrm{a}}$ & $1.0 \pm 0.1^{\mathrm{a}}$ & $0.1 \pm 0.0^{\mathrm{a}}$ \\
\hline \multirow[t]{2}{*}{$\mathrm{C} 3$} & $\% d w$ & $17.7 \pm 1.8^{\mathrm{a}}$ & $82.3 \pm 1.8^{\mathrm{a}}$ & $18.3 \pm 3.3^{\mathrm{d}}$ & $19.9 \pm 1.2^{\mathrm{de}}$ & $17.4 \pm 0.1^{d}$ & $7.3 \pm 0.7^{b}$ & $0.4 \pm 0.1^{a}$ \\
\hline & $\mathrm{g}$ & $3.1 \pm 0.5^{\mathrm{a}}$ & $14.5 \pm 1.0^{\mathrm{a}}$ & $3.2 \pm 0.8^{\mathrm{b}}$ & $3.5 \pm 0.2^{\mathrm{bc}}$ & $3.1 \pm 0.1^{\mathrm{b}}$ & $1.3 \pm 0.2^{\mathrm{b}}$ & $0.1 \pm 0.0^{\mathrm{a}}$ \\
\hline \multirow[t]{2}{*}{ C4 } & $\% d w$ & $18.6 \pm 2.1^{\mathrm{a}}$ & $81.4 \pm 2.1^{\mathrm{a}}$ & $14.1 \pm 0.5^{b c}$ & $13.7 \pm 2.3^{\mathrm{bc}}$ & $14.3 \pm 0.4^{\mathrm{a}}$ & $8.5 \pm 0.4^{c}$ & $0.7 \pm 0.1^{b}$ \\
\hline & $\mathrm{g}$ & $4.8 \pm 0.8^{\mathrm{b}}$ & $21.2 \pm 0.4^{\mathrm{b}}$ & $3.7 \pm 0.2^{\mathrm{bc}}$ & $3.5 \pm 0.6^{\mathrm{bc}}$ & $3.7 \pm 0.3^{\mathrm{d}}$ & $2.2 \pm 0.1^{\mathrm{d}}$ & $0.2 \pm 0.0^{\mathrm{b}}$ \\
\hline \multirow[t]{2}{*}{$\mathbf{P 1}$} & $\% d w$ & $16.7 \pm 2.1^{\mathrm{a}}$ & $83.3 \pm 2.1^{a}$ & $14.7 \pm 0.5^{\mathrm{c}}$ & $15.6 \pm 0.6^{c}$ & $15.7 \pm 0.1^{c}$ & $10.1 \pm 0.3^{d}$ & $0.9 \pm 0.1^{c}$ \\
\hline & $\mathrm{g}$ & $4.6 \pm 0.9^{b}$ & $23.1 \pm 0.3^{\mathrm{c}}$ & $4.1 \pm 0.2^{\mathrm{c}}$ & $4.3 \pm 0.8^{c}$ & $4.4 \pm 0.1^{\mathrm{e}}$ & $2.8 \pm 0.1^{\mathrm{e}}$ & $0.2 \pm 0.0^{\mathrm{c}}$ \\
\hline \multirow[t]{2}{*}{$\mathbf{P 2}$} & $\% d w$ & $16.7 \pm 0.2^{\mathrm{a}}$ & $83.3 \pm 0.2^{\mathrm{a}}$ & $11.3 \pm 2.3^{\mathrm{ab}}$ & $9.6 \pm 2.3^{\mathrm{a}}$ & $14.8 \pm 0.3^{b}$ & $6.5 \pm 0.3^{\mathrm{ab}}$ & $1.1 \pm 0.2^{\mathrm{c}}$ \\
\hline & $\mathrm{g}$ & $5.5 \pm 0.1^{\mathrm{c}}$ & $27.6 \pm 0.1^{\mathrm{d}}$ & $3.7 \pm 0.8^{\mathrm{bc}}$ & $3.6 \pm 0.2^{\mathrm{b}}$ & $4.9 \pm 0.3^{\mathrm{f}}$ & $2.1 \pm 0.1^{\mathrm{d}}$ & $0.4 \pm 0.1^{\mathrm{d}}$ \\
\hline
\end{tabular}


636 TABLE II: Amino-acids composition of extracts (g/100 g proteins)

637 Ala: alanine; Asp : aspartic acid; Glu : glutamic acid; Gly: glycine; His : histidine;

638 Hyp : hydroxyproline; Ile: isoleucine; Leu: leucine; Lys : lysine; Met : methionine;

639 Phe : phenylalanine; Pro : proline; Ser : serine; Thr : threonine; Tyr : tyrosine; Val:

640 valine.

\begin{tabular}{lccccccc}
\cline { 2 - 5 } & Blank & C1 & C2 & C3 & C4 & P1 & P2 \\
\hline Ala & 16.3 & 13.6 & 13.7 & 14.1 & 13.0 & 12.1 & 12.2 \\
Asp & 11.1 & 14.5 & 14.1 & 14.4 & 14.0 & 13.6 & 12.9 \\
Glu & 8.1 & 13.2 & 13.1 & 14.3 & 12.8 & 11.0 & 9.3 \\
Gly & 11.1 & 9.0 & 9.0 & 8.9 & 8.7 & 8.7 & 9.1 \\
His & 1.1 & 0.9 & 1.1 & 1.0 & 1.1 & 1.2 & 1.3 \\
Hyp & 2.3 & 2.3 & 2.1 & 2.0 & 1.7 & 1.4 & 1.7 \\
Ile & 5.2 & 5.2 & 5.3 & 5.1 & 5.3 & 5.4 & 5.2 \\
Leu & 8.4 & 7.1 & 7.3 & 7.0 & 7.6 & 8.3 & 8.8 \\
Lys & 2.6 & 3.0 & 3.2 & 3.1 & 2.9 & 2.8 & 2.5 \\
Met & 0.8 & 0.8 & 0.8 & 0.8 & 1.0 & 1.0 & 1.1 \\
Phe & 4.9 & 4.3 & 4.0 & 3.9 & 4.6 & 5.5 & 6.3 \\
Pro & 6.6 & 5.9 & 6.3 & 6.0 & 6.3 & 6.7 & 6.9 \\
Ser & 5.6 & 5.4 & 5.1 & 4.8 & 5.4 & 6.4 & 6.8 \\
Thr & 6.9 & 6.4 & 6.3 & 6.0 & 6.7 & 7.2 & 7.4 \\
Tyr & 1.5 & 1.2 & 1.3 & 1.2 & 1.4 & 1.4 & 1.4 \\
Val & 7.4 & 7.1 & 7.3 & 7.2 & 7.3 & 7.2 & 7.0 \\
\hline
\end{tabular}

641 
642 TABLE III: Simple sugars composition of extracts (a) and isolated polysaccharide 643 fractions (b) (g/100g total sugars).

644 Rha: rhamnose; Gal: galactose; Glc: glucose; Xyl: xylose; UAc: Uronic Acids. 'Other 645 sugars' represents the sum of low concentrated and non-identified sugars.

\begin{tabular}{lcccccc}
\cline { 2 - 5 } (a) & Rha & Gal & Glc & Xyl & UAc & Other Sugars \\
\hline Blk & 40.0 & 6.7 & 26.2 & 4.4 & 13.6 & 9.2 \\
C1 & 33.5 & 5.0 & 36.4 & 4.5 & 11.3 & 9.3 \\
C2 & 27.2 & 3.8 & 32.5 & 4.0 & 8.8 & 23.5 \\
C3 & 26.9 & 3.6 & 36.4 & 3.8 & 9.2 & 20.1 \\
C4 & 26.1 & 3.9 & 48.8 & 2.5 & 10.1 & 8.6 \\
P1 & 30.6 & 3.9 & 28.1 & 2.8 & 11.9 & 22.6 \\
P2 & 35.1 & 4.3 & 31.7 & 4.2 & 14.1 & 10.4 \\
\hline (b) & Rha & Gal & Glc & Xyl & UAc & Other Sugars \\
\hline B1k $p$ & 45.8 & 4.3 & 23.6 & 5.4 & 12.6 & 8.2 \\
C1 $p$ & 53.7 & 4.4 & 15.5 & 4.1 & 13.4 & 8.7 \\
C2 $p$ & 53.4 & 5.1 & 9.2 & 4.3 & 16.5 & 11.5 \\
C3 $p$ & 55.6 & 4.4 & 11.4 & 3.7 & 13.7 & 11.3 \\
C4 $p$ & 42.3 & 4.7 & 26.0 & 5.4 & 13.1 & 8.5 \\
P1 $p$ & 41.9 & 3.9 & 26.2 & 5.1 & 13.1 & 9.7 \\
P2 $p$ & 47.9 & 4.5 & 20.8 & 4.6 & 13.6 & 8.7 \\
\hline
\end{tabular}

646

647 


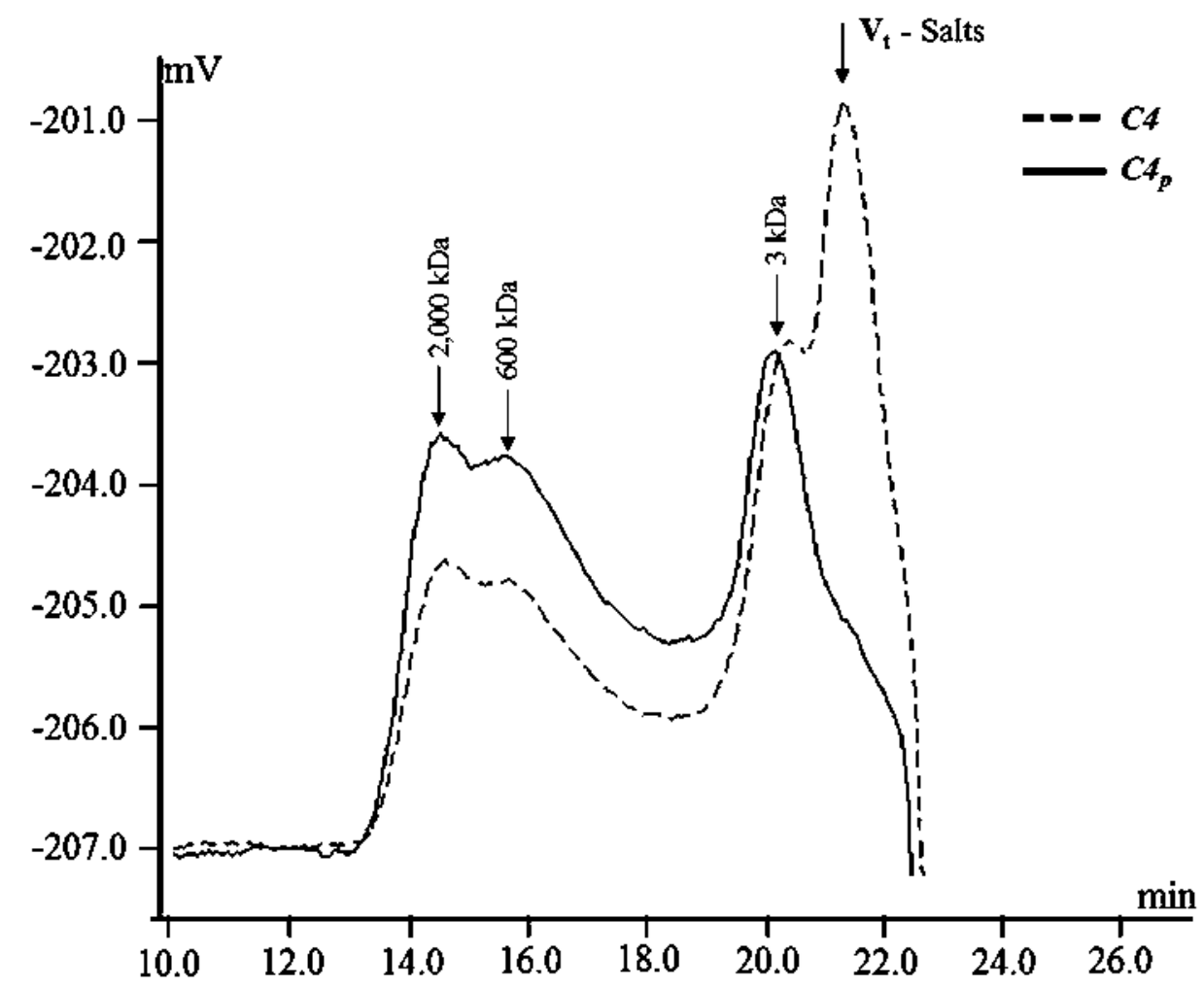

648

649 Figure 2: High pressure steric exclusion chromatogram (RI) of samples $\mathrm{C} 4$ and $\mathrm{C} 4_{p}$,

650 before and after ethanol precipitation.

651 Flow: $0.5 \mathrm{ml} / \mathrm{min}$; Pressure: 9-13 bars; Eluent: 0.1 M NaNO3; Sample: $1 \mathrm{mg} / \mathrm{ml}$; Inject.

652 vol.: $100 \mu \mathrm{L}$, detection: refractive index. $\mathrm{C} 4$ : dotted line; $\mathrm{C}_{p}$ : solid line.

653 
654 TABLE IV: Screening of in vitro cytotoxic, antiviral and antioxidant activities of crudes 655 extracts and polysaccharides fractions.

$656{ }^{*}$ BHA : Butylated HydroxyAnisole; ${ }^{* *}$ BHT : Butylated HydroxyToluene

\begin{tabular}{|c|c|c|c|c|c|c|}
\hline & & rude extract & & & Polysacc & Irides \\
\hline & Cytotoxicity & Antiviral & Antioxidant & & Cytotoxicity & Antiviral \\
\hline & $C C_{s 0}(\mu \mathrm{g} / \mathrm{ml})$ & $E C_{50}(\mu \mathrm{g} / \mathrm{ml})$ & $I_{50}(\mu \mathrm{g} / \mathrm{ml})$ & & $C C_{s o}(\mu \mathrm{g} / \mathrm{ml})$ & $E C_{50}(\mu \mathrm{g} / \mathrm{ml})$ \\
\hline Acyclovir & $>500.0$ & $0.3 \pm 0.1$ & - & & $>500.0$ & $0.3 \pm 0.1$ \\
\hline BHA $^{*}$ & - & - & 0.0048 & & - & - \\
\hline BHT $^{* *}$ & - & - & 0.0069 & & - & - \\
\hline Blk & & & $>25.0$ & Blk $_{p}$ & & $>500.0$ \\
\hline C1 & & & 6.0 & $\mathrm{C1}_{p}$ & & $373.0 \pm 20.7$ \\
\hline $\mathrm{C} 2$ & & & $>25.0$ & $\mathbf{C} 2_{p}$ & & $>500.0$ \\
\hline C3 & $>500.0$ & $>500.0$ & $>25.0$ & $\mathbf{C} 3_{p}$ & $>500.0$ & $>500.0$ \\
\hline $\mathrm{C} 4$ & & & $>25.0$ & $\mathrm{C4}_{p}$ & & $320.9 \pm 33.6$ \\
\hline P1 & & & 1.8 & $\mathbf{P} 1_{p}$ & & $>500.0$ \\
\hline P2 & & & 12.5 & $\mathbf{P} \mathbf{2}_{p}$ & & $>500.0$ \\
\hline
\end{tabular}

657

658 